\title{
Drónos logisztikai megoldások vizsgálata a kiskereskedelemben
}

\section{Examining drone logistics solutions in retail}

\author{
I. FÜZESI ${ }^{1}$, SZ. PREZNYÁK ${ }^{2}$, R. SZILÁGYI ${ }^{3}$, P. LENGYEL ${ }^{4}$ \\ 1Debreceni Egyetem, Gazdaságtudományi Kar, Üzleti Informatika Tanszék, fuzesi.istvan@econ.unideb.hu \\ 2Debreceni Egyetem, Gazdaságtudományi Kar, preznyakszabolcs@yahoo.com \\ 32Debreceni Egyetem, Gazdaságtudományi Kar, Üzleti Informatika Tanszék, szilagyi.robert@econ.unideb.hu \\ ${ }^{4}$ Debreceni Egyetem, Gazdaságtudományi Kar, Üzleti Informatika Tanszék, lengyel.peter@econ.unideb.hu
}

\begin{abstract}
Absztrakt. A drónok szállitásban való alkalmazásának lehetőségeit a drón technológia adottságai, a jogszabályok, a különböző érdekképviseletek és szakszervezetek, valamint az általános elfogadottság mértéke fogja meghatározni. A technológia és infrastruktúra adott, a vásárlói szokások és igények kedvezőek, és a két pont közt mozgó csomagok generálta károsanyag-kibocsájtás folyamatosan nô. E kedvező feltételek ellenére alaposan át kell tekinteni az drónok alkalmazásával járó hatásokat. A projekt megvalósítását érintő tág környezet a PEST analízissel, a fontosabb befolyásoló tényezőket Porter-féle öttényezős modell segítségével vizsgáltuk. A kérdőives felmérésen és a készétel-kiszállitás megvalósíthatósági vizsgálatain alapuló eredményeinket követôen elmondható, hogy egy drónos szállitáson alapuló rendszer hatékonyan terítő-körjáratok alkalmazásával lehet müködöképes és költséghatékony, azonban a drónos szállítási lehetőségeknél felmerülő jogi kérdések és bizonytalanságok még jó ideig igen jelentôs hátráltató tényezőként maradnak meg.
\end{abstract}

Abstract. The possibilities of using drones in transportation will be determined by the capabilities of drone technology, legislation, various advocacy and trade unions, and the degree of general acceptance. Technology and infrastructure are given, customer habits and needs are favourable, and emissions generated by packets moving between two points are growing steadily. Despite these favourable conditions, the effects of drone use should be thoroughly reviewed. The environmental impacts of the project were analyzed by PEST analysis and the main influencing factors were studied using the Porter model. Concluding our results based on questionnaire surveys and feasibility examinations of fast food delivery, it can be said that a system based on drones can efficiently be operated and cost-effective using round trips, however, the legal issues and uncertainties that arise in the delivery of drone shippers remain a very significant hindering factor for a long time.

\section{Bevezetés}

A 21. század elején a népességnövekedés, az urbanizáció és a vásárlói réteg igényeinek növekedése révén az előállított áruk száma, a címzett és megrendelő közti árumennyiség forgalma is megváltozott, ezáltal az utak sűrűsége és zsúfoltsága egyre inkább kritikussá válik, akárcsak az energiafelhasználás és a káros-anyag kibocsájtás. Napjainkban a pilóta nélküli légi járműveket számos területen eredményesen alkalmazzák. Nem volt kérdés, hogy előbb-utóbb a szállítmányozás területén is 
tesztelik a felhasználási lehetőségeket, gazdagítva a logisztika területét. Az e-kereskedelem térnyerése pedig megfelelő közeget biztosít a szállításra alkalmas drónok számára. Nehezen megválaszolható, de annál is érdekesebb kérdés, hogy ez lesz-e az új meghatározó szállítási mód, vagy a csomagok továbbítására alkalmas pilóta nélküli légi járművek térnyerése egy újabb logisztikában alkalmazhatatlan zsákutcának bizonyul. [1]

Az áruszállítás elsőszámú feladata a vásárlók igényeinek maximális kielégítése az ehhez szükséges költségek minimalizálása mellett, mely a tapasztalatok alapján gyakran ellentmondásos. Az igények megfelelő kielégítése magasabb költségekkel jár, míg a költségek lehetséges minimalizálása mellett nem lehet megfelelni kellőképpen a vásárlói elvárásoknak. [2] Nemcsak a költségek tekintetében van jelentős szerepe az áruszállítással foglalkozó logisztikai feladatoknak és megoldásoknak. Az áruszállítási folyamatok logisztikai döntései gyakran és kikerülhetetlenül az egyéb vállalati területek folyamatait és döntéseit is befolyásolják. Esetünkben jelentősen módosítják a technológiai tevékenységeket és fejlesztéseket, de a marketinget, raktárgazdálkodást és készletezést, beszerzést, termelést, s nem utolsó sorban a csomagolási eljárást is.

A számos árutovábbítási döntés közül, a továbbítás módjának kiválasztása (azaz saját fuvareszközzel szállítsunk, vagy vonjunk be egy harmadik félt, fuvarozót, szállítmányozót), a fuvareszköz kiválasztása (környezetvédelmi, pénzügyi szempontok alapján), rugalmasság mértékének kialakítása, biztonság kérdése, illetve a szállítási idő és a szállított áruk mennyisége azok, melyeknek jelentős fontosságot tulajdoníthatunk.

Kutatásunk fő kérdése, hogy kivitelezhető-e a készétel kiszállítás teljes automatizálása a drónokban rejlő lehetőségek megragadásával, amennyiben igen, milyen módon és milyen feltételek mellet? A kérdés közérthető elemzése és megválaszolása érdekében a megvalósíthatósági tanulmányok logikai felépítését követve mutatjuk be eredményeinket. Ennek keretében tanulmányunkban hangsúlyt helyezünk a környezeti hatások vizsgálatára, a szükségletek, valamint a beruházás gazdaságossági elemzésekre.

\section{Drónok háttér elemzése és értékelése}

A drónok közérthetően talán úgy mutathatók be, mint repülő robotok. A civil életben az eszközök viszonylag későn, a 90-es évek során jelentek meg és felhasználásuk eleinte jellemzően tudományos feladatokra korlátozódott. Napjainkban az eszközök rendkívül színes palettája áll rendelkezésünkre, valamint az eszközökkel végzett feladatok és a bennük rejlő lehetőségek köre is szélesedik. [3] [4] A pilóta nélküli légi járművek fizikai alakját, kapacitását, képességeit az alkalmazási terület befolyásolja. [5] Általános osztályozásnak tekinthető a drónok építési típusán alapuló megkülönböztetés. Ennek alapján négy kategóriába sorolhatjuk a pilóta nélküli légi járműveket:

- Fixed-Wing, azaz a rögzített szárnyú, amely stabilabb szerkezetűek és hosszú távot képesek megtenni. Külsejét tekintve inkább hasonlít egy miniatűr vadászgépre.

- Unmanned Helicopter, magyarul pilóta nélküli helikopter, mely nehezebb rakománnyal is megbirkózik, manőverezhetőség és egyszerű irányíthatóság jellemzi. 
- Tilt-Wing, azaz a döntött szárnyú, mely a rögzített szárnyú és a pilóta nélküli helikopter keveréke. Drága és komplex eszköz.

- Multicopter, mely könnyű szerkezetű, olcsó, egyszerűen kezelhető, csöndes, ámbár teherbírását tekintve jelentős korlátokkal rendelkezik, mindamellett a szél erőssége (de a hőmérséklet) is negatív hatást gyakorol a repülőképességére. [5]

Súlyuk alapján lehetnek: nagyon nehezek (super heavy) - ezek 2000 kg fölötti gépek, nehezek, melyek súlya 200 és $2000 \mathrm{~kg}$ között van, közepes súlyúak, 50 és $200 \mathrm{~kg}$ között, az 5 és $50 \mathrm{~kg}$ közötti pilóta nélkülieket nevezzük könnyü gépeknek, illetve vannak meg a mikro drónok, melyek súlya nem haladja meg az 5 kg-ot. Repülési képességük alapján lehetnek: nagy teljesítményűek, közepesek és gyengék. A nagy teljesítményű drónok 24, vagy annál több órát is képesek a levegőben tölteni, ez alatt 1500 22000 kilométer távolságot is képesek megtenni. A közepes teljesítményű drónok 100 - 400 kilométert tesznek meg, és egyetlen feltöltéssel minimum 5, maximum 24 órát képesek repülni megállás nélkül. A kis teljesítményű gépek 5 óránál nem többet képesek repülni újabb feltöltés nélkül, megtéve ez alatt az idő alatt kevesebb, mint 100 kilométert. [4] Cikkünkben a multikopter típus alkalmazási lehetőségeit vizsgáljuk, mely a legközkedveltebb típus, bár szinte minden említett kategóriában a leggyengébbek közé tartozik, mégis könnyen kezelhető, kis fesztávolságú, kis energiaszükségletű és környezetbarát.

\subsection{A drónok szállításban való alkalmazásának lehetőségei, veszélyei és feltételei}

A drónok használatára és alkalmazására vonatkozó szabályozások az Egyesült Államokban és az európai országokban is többnyire kiforratlanok és folyamatosan változnak. Nem szabad viszont figyelmen kívül hagynunk a tényt, hogy a drónok gazdaságban való alkalmazásához nem csupán a légi közlekedésért felelős szervek hozhatnak törvényt és szabályozást. Tökéletes példa erre Japán, ahol már 2004-ben az elhagyatott mezőgazdasági területeken a pilóta nélküli helikopterek váltották le az addigi permetező repülőgépeket, a Mezőgazdasági, Erdészeti és Halászati Minisztériumnak köszönhetően, megkerülve a Japán Mezőgazdasági Légiforgalmi Társaságot. [7] Megállapíthatjuk, hogy egy új szállítási mód várakozik megfelelő jogszabályi környezet kialakítására, hiszen a drónok logisztikai feladatokra történő alkalmatlanságának okaként sok helyen a jogszabály hiányát említik elsőként, ha a drónos szállítás akadályairól vagy feltételeiről esik szó.

A drónok logisztikai feladatokra való alkalmazásának további jelentős veszélye, hogy a drón a csomaggal együtt a földbe csapódhat, a drónok összeütközhetnek, melyből következik a drón meghibásodása és egyes esetekben a csomag megrongálódása, megsemmisülése. Ezenfelül becsapódáskor jelentős sérülést és kárt okozhat úgy az épületekben, gépjárművekben, mint az emberekben és állatokban, növényekben egyaránt. A közútrendszernél összetettebb és legalább olyan mértékű felügyeletet és szabályozást igényel majd a drónok által használni kívánt légtér pályáinak hálózata. A technikai meghibásodáson túlmenő veszélyként legalább ekkora fajsúllyal bír a személyi tulajdon ellen elkövetett szabálysértés (a drón feladatában való bármiféle akadályozás, pl.: hacker támadás vagy eltérítés, szándékos vagy véletlen fizikai sérülés okozása, lopás, stb., vagy akár a drón vezérlőjének hibájából fakadó szabálysértés, károkozás, személyi jogok megsértése). Ezen felül 
számolni kell a csomag értékével összefüggő és a csomag kézbesítésének sürgető mivoltából fakadó veszélyekre (pl.: gyógyszerek, elsősegély csomag). [7] [8] [9]

Jelentős veszély jelent a drónok számának rohamos növekedése, e gépek ellenőrzésének nehézsége, valamint az, hogy a szállításra fejlesztett drónok jelenleg még nem képesek tökéletesen észlelni környezetüket és az emberei beavatkozás nélküli mesterséges intelligencia végképp nem megbízható. Nem csupán a drónok ellenőrzését kell majd biztosítani, hanem az egyéb szállítási módokhoz hasonlóan a rakományt és tartalmát is, azaz a küldeményt. Ez pedig legalább olyan fontos, mint az szállítóeszköz szabályozása, nyilvántartása, ellenőrzése és nyomon követése. [7]

A drónok szállításra való használatának legnagyobb előnye a drón energiafelhasználásában rejlik. A módszer környezetbarát, ezáltal a zsúfolt városok, a zajszennyezés és úthálózatok problémájára is megoldás lehet. A drónos szállítás feladó és címzett számára érzékelt előnyei a drónok képességeiből erednek, ugyanis a drón képes nehezen elérhető helyekre (pl.: hegytető) szállítani gyorsan (légvonalban) és egyszerűen, konkrét és pontos koordináták alapján akár a megrendelő „kezébe”. Hátránya úgyszintén a drónok képességeiből ered, az elszállítandó csomag mérete és súlya, valamint a címzett-feladó között távolság azok, amik egyelőre korlátot képeznek. Mindamellett egyértelmű, hogy az alacsonyabb szállítási költség, ha nem is azonnal, de idővel a termék fogyasztói árában is megmutatkozik.

\subsection{PEST elemzés}

A projekt megvalósítását érintő tág környezet a PEST analízis alapján kerül bemutatásra. Fő kérdés az volt, hogy adott környezet gátolja-e, vagy elősegíti, azaz pozitívan vagy negatívan hat a projekt megvalósíthatóságra. A közvetlen kapcsolt jogszabály a cikk írása idejében Magyarországon még nem került kialakításra. Éppen ezért nem lehet megbízhatóan értékelni a képlékeny jogi környezetet. Azonban a drónos élelmiszer szállításra vonatkozhat az 1995. évi XC. törvény élelmiszerek forgalomba hozatalának feltételeire vonatkozó, a hatósági ellenőrzésre vonatkozó rész, mely szerint meg kell oldani az ellenőrizhetőséget. A jogi, politikai környezet elemzése esetünkben igen komplex kérdéskör. Figyelembe kell venni a Környezetvédelmi Hatóság ellenőrzéseinek elkerülhetetlenségét (környezetvédelmi engedélyek szükségessége), a Katasztrófavédelmi Hatóság bevonásának szükségességét, valamint kihagyhatatlanul és nem utolsó sorban a Nemzeti Közlekedési Hatóság Légügyi Hivatalának jelentős befolyását. A politikai tényezők vizsgálati eredményei stabil és váratlan lépésektől mentes jogi, politikai környezetet mutatnak. Elmondható tehát, hogy a jogi, politikai környezet a cél elérését tekintve gátló tényező (ami nagyrészt a jogszabály hiányának köszönhető). A fogyasztói és vásárlói szokások mélyebb és részletesebb elemzése révén azt is meg tudnánk mondani, hogy esetünkben milyen jelentőséggel bír a diszkrecionális jövedelem. A drónos szállításhoz köthető gazdasági környezet megbízhatóbb és változásai könnyebben előre jelezhetőek, mint a jogi, politikai környezet.

A technológiai környezet vizsgálatánál a legjelentősebb kérdés, hogy mennyire terjedt el az adott területen az online vásárlás, a drónos szállításhoz szükséges támogató-technológiai infrastruktúra mennyire kiépített, illetve, hogy mennyire, milyen mértékben elfogadott, bevált és rutinszerú az elektronikus fizetési mód. Az online vásárlás növekvő ütemben, lassan minden háztartásba 
begyűrűzik, és nemcsak a műszaki cikkek piacán. Egyre több szereplővel gazdagodik az ekereskedelem, megnövelve a mozgó áruk számát. Az elektronikus fizetési mód kedveltségének és elterjedésének kérdése viszont nem ennyire egyszerűen megválaszolható. Elképzelhető lehet egy drónra felszerelt terminál (POS terminál) alkalmazása, esetleg mobil fizetési lehetőség használata.

\subsection{Porter-féle öttényezős modell}

A Porter-féle öttényezős modell segítségével a fontosabb befolyásoló tényezőket vizsgáltuk. Versenytársak fenyegetettsége alacsonynak tekinthető. A vizsgált portál versenytársa Debrecenben 15 partnerre építi tevékenységét. Kiterjedését és ismertségét tekintve elmarad több multinacionális portál mögött. Az új belépők fenyegetettsége szintén alacsony. Habár az e-kereskedelemi piac korlátai minimálisak, a drónos szállítás, mint szolgáltatás megteremtése tőke-, de még inkább tudásigényes. A szállítók alkupozíciója alacsony. Jelen tényállás szerint a világon bárki tud drónt vásárolni, viszonylag kedvező áron. Egyre több gazdasági szereplő állít elő drónokat. Amíg nem fenyeget speciális alkatrész igény, addig alacsonyan tartható a szállítók alkupozíciója.

A vevők alkupozíciója kettős, mivel a létrehozni kívánt szolgáltatásnak két haszonélvezői csoportja van, egyik a jelenlegi és potenciális partnerek, míg a másik a közvetett célközönség. Mindkét csoport vevőinek száma magas (az előbbi csoportban nincs kimagasló piaci részesedéssel rendelkező), és a szolgáltatás különleges, melyek tekintetében a vevők alkuereje alacsonynak mondható. Ezen felül viszont nem szabad figyelmen kívül hagynunk azt a tényt, hogy számos választási lehetőség áll a vevők rendelkezésére [10], amely megkérdőjelezheti alkupozíciójuk minősítését.

A helyettesítő termékek fenyegetettsége magasnak mondható. A közvetlen haszonélvezők (névleges megfogalmazás: a jelenlegi és potenciális partnerek) dönthetnek úgy, hogy a már jól bevált szállítási módok valamelyikét választják, megtartják, míg a közvetett haszonélvezők étkezési szokásainak trendvizsgálati eredményeit felborítva választhatják az otthoni főzést, az éttermi étkezést, vagy maradhatnak a hagyományos módon érkező készételek rendelése mellett.

\subsection{A drónok ismertsége és elfogadottsága Magyarországon}

A fentiekben említett szükségletek vizsgálatának elengedhetetlen része a potenciális piaci szereplők véleményének felmérése. Éppen ezért kérdőíves felmérést végeztünk, mely esetünkben a mintát tekintve nem nevezhető minden szempontból reprezentatívnak, ezért különböző szignifikancia és korreláció vizsgálatokat nem is végeztünk rajta. Azonban a jelenlegi hazai és nemzetközi drónok szállításban való alkalmazásának lehetőségeit és a korábbiakban leírt helyzetjelentéseket árnyalhatja, valamint megismerhetjük a fogyasztói piac témához való hozzáállását, ismeretét és várakozásait. Összesen 270 fogyasztóhoz jutott el a kérdőív, 150-en töltötték ki on-line, 120-an pedig nyomtatott formában.

A hagyományos demográfiai kérdések után elsőként azt vizsgáltuk, hogy a megkérdezettek milyen információkkal rendelkeznek a drón-technológia területén, főleg a hobbi drónok magas hazai és nemzetközi eladásáról szóló hírek tükrében. Mivel a válaszadók túlnyomó többsége, (több mint 73\%- 
a) nyilatkozott úgy, hogy látott már drónt működés közben (nem video felvételen) megvizsgáltuk, hogy ennek alapján hányan tartják veszélyesnek a drónok alkalmazását.
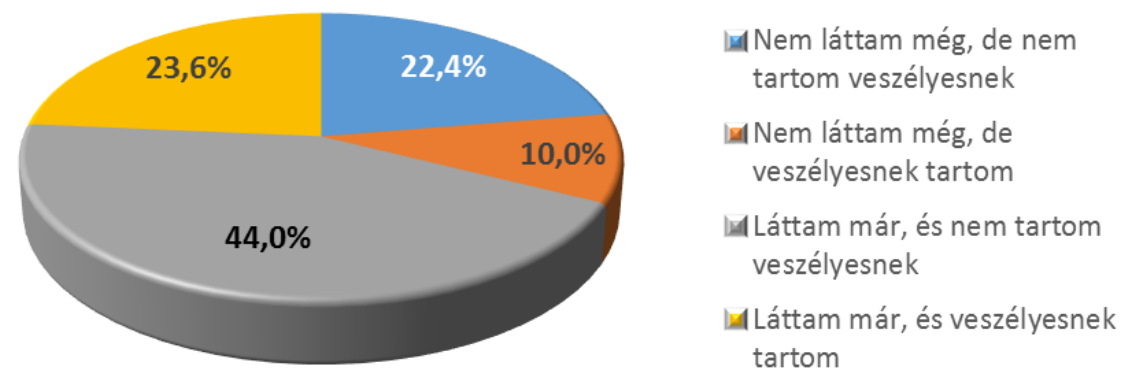

1. ábra: A drónok ismertségének és elfogadásának aránya

Az 1. ábra jól érzékelteti, hogy bár a megkérdezettek 65,2\%-a nem tartja veszélyesnek a pilóta nélküli légi járművek szállításban való alkalmazását, az erre vonatkozó kérdés mind a két tábort jelentősen megosztotta, ami nem csoda. E kérdés sokkal alaposabb kutatást igényel, melynek eredményeként célzott akciótervet lehet készíteni ismeretterjesztő céllal, és ahogyan az a kérdőív felméréseiből kiderült, még azt sem lehet egyértelműen megállapítani, hogy a technológia iránti nyitottságban és a veszélyforrások súlyának egyéni értékelésében való eltérés korcsoport függő lenne. Számos esetben a fizikai sérülést emelték ki a megkérdezettek, mint legvalószínűbb és legalapvetőbb rizikófaktort.

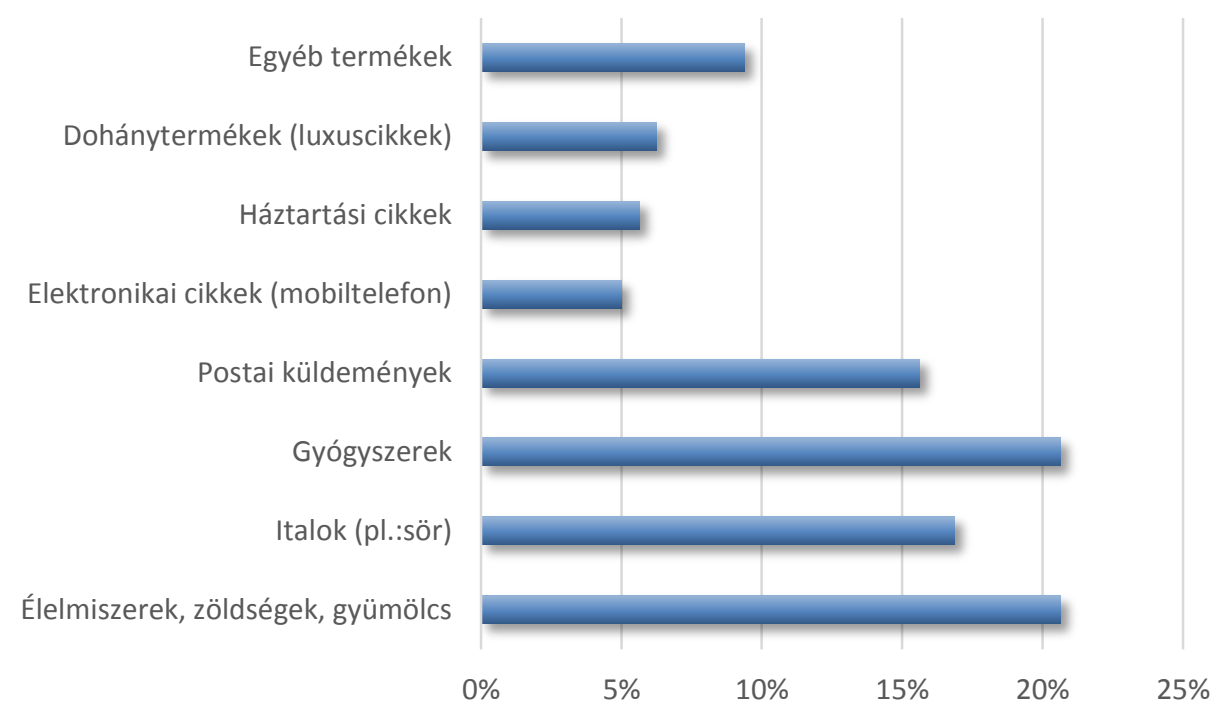

2. ábra: A drónos kiszállítás által igényelt termékek

A szükségletek elemzésének fontosabb kérdése, hogy mely termékek gyors kiszállítására, vagy egyszerűen csak online vagy telefonos formában történő rendelésleadást követő kiszállításra lenne 
igény. A kereskedelemben a drónokat elsősorban nagy értékű, de kisméretű, főként elektronikai termékek szállítására szánták, mely elgondolásnak költségtényezős mozgatórugói voltak. Ez viszont felmérésünk szerint egyáltalán nem egyezik meg a hazai piac igényeivel (2. ábra).

\section{Disztribúciós hálózat és járattervezés}

A továbbiakban arra kérdésre keresünk választ, hogy milyen szempontokat kellene figyelembe venni egy drónokkal történő ételkiszállítás megvalósítása esetén. A vizsgálatainkat egy debreceni készétel rendelési portál példáján (adatai segítségével) keresztül végeztük el. A készétel-kiszállítás teljes automatizálása nem kis beruházást jelentene a Magyarországon piacvezető készétel-rendelési portálnak, mely fejlesztés szükségessége nem meglepő annak függvényében, hogy mind a piaci húzóerő, mind a technológia nyomása igen jelentős. Éppen ezért a vizsgálatok fontos részét képezik a megvalósíthatósági tanulmányok részeként a disztribúciós hálózat és a járat-tervezés, útvonaltervezés kiválasztásának vizsgálata, valamint a szükséglet vizsgálat. Az 1999-ben elindított online készétel rendelési portál célja, hogy a lehető legtöbb készétel-házhozszállítási szolgáltatást nyújtó éttermet egy helyen gyűjtse össze a vásárlók feladatának megkönnyítése érdekében. A város és étterem kiválasztását követően a portál felületén lehetőség van a rendelés leadására, ezután a portál továbbítja, illetve adott esetben átvállalja a szállítási feladatokat. Jelenleg Debrecenben 22 partnerrel dolgoznak együtt, zömében pizzériákkal. A 22 partner közül 13 étterem adott ki kiszállításokra vonatkozó teljes, vagy rész információt. Esetünkben a releváns kérdések, hogy az adott étterem egy nap hány fuvareszközt üzemeltet és átlagosan hány megrendelést (cím) teljesít adott munkanap. Ez alapján került kiszámításra, hogy egy fuvareszközzel (túlnyomó többségben személygépjármű) egy nap alatt átlagosan hány megrendelést (cím) teljesítenek, vagyis egy fuvareszköz egy nap átlagosan 36,8 címzetthez jut el. Az adott információk alapján (a partnerek átlagosan 2,2 fuvareszközt üzemeltetnek egy nap) meghatározható, hogy a partnerek együttesen 1781,12 megrendelést teljesítenek. A 22 étterem ezt a közös 1781 címet délelőtt 10 órától éjjel fél 4-ig teljesíti, de átlagosan 11 órától este 22 óra 30 percig, azaz 11 és fél óra alatt (az egyszerűség kedvéért 12 óra/nappal számolunk). Ez kerekítve óránkénti 148 megrendelés teljesítését jelenti 22 étteremmel számolva. A további számítások során egy napot három periódusra bontunk fel, mindegyik periódus 4 órát ölel fel a 12-ből. Az első periódus a délelőtti időszak (11:00-15:00), a második a délutáni időszak (15:0019:00), illetve az esti időszak (20:00-23:00). Mivel zömében pizzára és gyorsételre specializálódott vendéglátóhelyekről van szó, az átlagos forgalmi trendek alapján úgy bontottuk fel a rendeléseket, hogy a délelőtti időszakra a megrendelések 10\%-a, a délutánira a megrendelések 30\%-a, míg az esti időszakra a megrendelések 60\%-a esik

$$
\left(\frac{1781 \text { cím } * 60 \%}{4 \text { óra }}=267 \frac{\text { cím }}{\text { esti óra }}\right) \text {. }
$$

A portál automatizált kiszállítás tervének vizsgálata folyamán a következő átvett és kalkulált információkat és adatokat, feltevéseket alkalmaztuk: 
A drónokra vonatkozó kapacitás információk

\begin{tabular}{l|}
\hline Maximális teherbírás \\
A pilóta és az eszköz közötti \\
maximális távolság \\
Maximális sebesség \\
Maximális repülési idő \\
Teljes feltöltési idő \\
Emelkedési, leszállási, rakodási idő
\end{tabular}

\begin{tabular}{|r|lr}
$18,7 \mathrm{~kg}$ (Spider Drone) & 1 liter üzemanyag ára & $400 \mathrm{Ft}$ \\
$30-40$ kilométer (Spider Drone) & 1 kWh elektromos energia ára & $35 \mathrm{Ft}$ \\
$80 \mathrm{~km} / \mathrm{h}$ (Amazon Prime Air) & Egy szállításra alkalmas drón értéke & $1000000 \mathrm{Ft}$ \\
$30 \mathrm{perc/töltés} \mathrm{(Spider} \mathrm{Drone)}$ & Egy útra elegendő feltöltés költsége & $10 \mathrm{Ft}$ \\
1 óra & Drón várható üzemideje & 5 év \\
1 perc & Csomagok/címek átlag tömege & $1 \mathrm{~kg}$
\end{tabular}

1. táblázat: A számításokhoz felhasznált alapadatok

\section{Alkalmazandó költség információk}

Egy pilóta a vezérlési egységből egy időben 10-12 drón akcióját tudja kezelni, valamint az egyszerűség kedvéért tekintsünk el a drónokra vonatkozó hazai jogszabály hiánytól, így azzal a feltételezéssel élünk, hogy az engedélyek beszerzése, ára és egyéb kapcsolódóan felmerülő folyamatok és azok költségei (pl.: útadó, kötelező biztosítás, stb.;) a közúti szabályoknak megfelelően alakulnak. A készételek csomagolására vonatkozó minőségbeli és méretbeli előírásokat és alkalmazásokat egységesnek tekintünk mind a 22 partnernél, megkönnyítve az egységrakomány képzést. Ennek köszönhetően egy drón polcszerű „raktérrel” képes egyszerre több, azonos méretű és fizikai tulajdonságú csomagot szállítani. A karbantartási költségeket a OneDrone.com Szlovéniai szolgáltató webshop kínálatának árai alapján számoltuk, a személygépjármű esetén felmerülő alapvető karbantartási költségekhez, kötelező szervizköltségekhez viszonyítva, amelyekkel párhuzamot lehet vonni.

\section{1. Útvonaltervezés és eloszlás irányítása}

A szükséges kapacitásokat azért kell meghatározni, mert nem minden járattípus igényel azonos számú (azonos raktérrel és egyéb azonos tulajdonságokkal rendelkező) szállító eszközt, és ennek függvényében az adott költségek is változni fognak. A kérdés adott, vagyis, mely járattípus, rendszer alkalmazása lesz az optimálishoz legközelebb eső választás a drónok alkalmazása számára. A vizsgálatból már a legelején ki kell zárni a szállítmányozói gyűjtőforgalom rendszert, gyűjtőkörjáratot és a vegyes körjáratot is.

A vizsgálati „ $\alpha ”$ járat megvalósítási alternatíva (továbbiakban: terv) a vonali forgalom, egyszerü járat alkalmazása, mely során a szolgáltatás igénybevétele esetén a drónok a partner éttermek közt kerülnek leosztásra (eszközbérlés), mivel azok adott „A” (étterem) és „B” pont (egy adott cím, megrendelési lerakóhely) között mozognak, egy központi irányítótorony segítségével. $A$ „ $\beta 1$ ” terv az „ $\alpha$ " tervhez hasonló, viszont ez esetben az egy helyen felvett csomagokat több helyen adja le, ez lesz az egyszerű terítő körjárat, áruterítő-rendszer alkalmazása. A „ß2” terv az árugyűjtő-áruterítő rendszer alkalmazása lesz, mely esetén a szolgáltatónak, rendelkeznie kell le legalább egy „drón-állomással”, „drón-depóval”, ahonnan a drón elindul, több partnernél megállva felveszi az árukat, majd pedig legalább két helyen leadja, végezetül visszatér a depóba és újratöltik, felkészítik a következő útra. $A$ „ $\gamma$ ” terv lesz a kerékagy-küllő rendszerhez hasonló kapcsolt járat alkalmazása, mely esetén szintén fennáll a központi „drón-depó”, „drón-állomás” szükségessége, annyi különbséggel, hogy itt a fuvareszköz töltésén túlmenően cross-docking rendszer működését is biztosítani kell. Az árukat a drónok több 
partnertől gyűjtik be, de a megfelelő rakomány összeállítását követően (címek területi szórása alapján) a drónok csupán a lehető legkedvezőtlenebb esetben továbbítanának egyetlenegy célállásra. Minden más esetben a csomagok depóba érkezését és összeállítását követően az áruterítő-rendszer lép életbe.

A négy alternatíva közül azt kell választanunk, amely költség és szolgáltatás minősége (gyors kiszállítás) alapján a legkedvezőbb. Éppen ezért a négy modellt egyazon elemekkel rendelkező 30 perces szimulációban került kipróbálásra, ahol a valós kiszállítási igény 25\%-ával volt kalkulálva (267 esti cím/óra*0,25=67 címzett), és ennek megfelelően kerültek kiválasztásra Debrecen városrészeinek népsűrűsége és jövedelmi szórása függő véletlenszerű megrendelői címek.

Tudjuk azt, hogy a kifejlesztendő drón, amely $80 \mathrm{~km} / \mathrm{h}$ sebességgel halad, 30 percig képes megállás vagy töltés nélkül működni, és 60 perc töltési időre van szüksége. Ez azt jelenti, hogy az általunk felállított feltevések függvényében (30 percből 6 percet vesz igénybe az egyszeri be és kirakodás, valamint a két-két függőleges emelkedés és ereszkedés) 32 kilométert képes megtenni, két, egymástól $16 \mathrm{~km}$ távolságra található pont között egy fordulóval. Ez kiváló az „ $\alpha$ ” terv szemszögéből, a területi adottságok függvényében (100-120 km2).

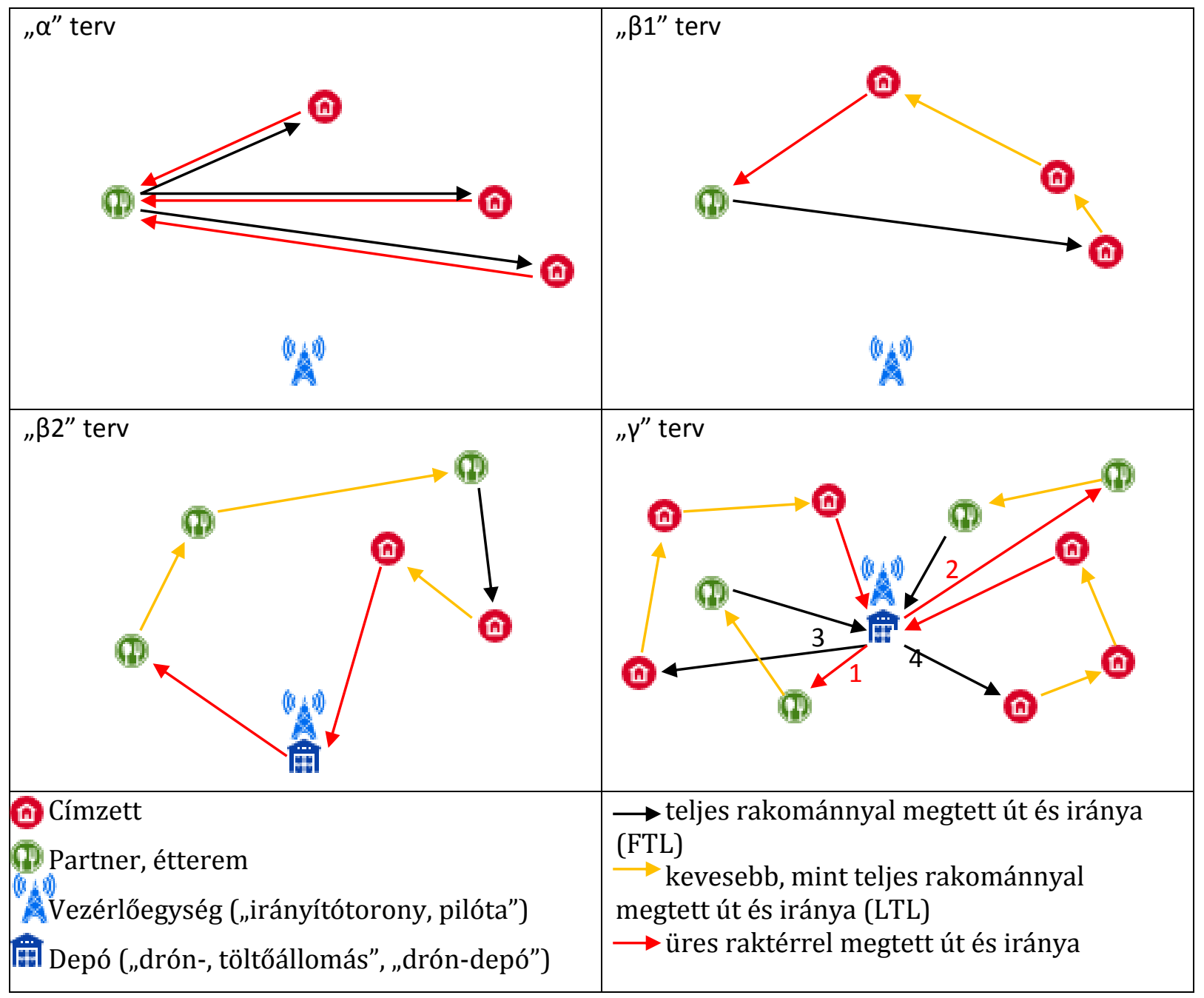

3. ábra: Alkalmazandó járattípus, rendszer tervei 
„ $\alpha$ " terv:

1 átlagtávolságú egyirányú út időigénye: $\frac{2,38 \mathrm{~km} * 60 \mathrm{perc}}{80 \mathrm{~km}}=1,8 \operatorname{perc}$

1 átlagtávolságú vonali, egyszerű járat időigénye (nevezőben = 9,6 perc), 30 perc alatt megtenni képes járatok száma:

30 perc aktív drón használati idő

$$
\begin{gathered}
\overline{1,8 \text { perc } * 2 \text { (oda, vissza út) }+6 \text { perc (be és kirakodás, emelkedés és erszkedés) }} \\
=3,13 \text { út, cím, } \frac{\text { kézbesítés }}{30 \text { perc }}
\end{gathered}
$$

A partnerek fejenkénti átlagos 30 percre eső megrendelése $=\frac{\frac{\frac{267 \text { esticím }}{60 \text { perc }}}{22 \text { partner }}}{2}=6 \frac{\text { cím }}{30}$ perc $/$ partner 30 percnyi megrendeléshez szükséges partnerenkénti drónok száma (átlag):

$\frac{6 \text { cím } 30 \text { perc alatt partnerenként }}{3,13 \text { kézbesítés } 30 \text { perc alatt drónonként }}=1,92 \approx 2$ drón; Mivel egy drón 60 percet töltődik, és ez alatt az idő alatt nem képes feladatának ellátására, szállításra, ezért egy nap 6 drónra lesz szükség, melyek párosával váltják egymást (félóránként: 4 töltődik, 2 akcióban).

A rendszernek ez esetben 132 drónra lenne szüksége: 22 partner $* 6$ drón

„ß1" terv:

Átlagtávolság a generált címek között (adott 60 percben aktuális 12 megrendelő esetén, szomszédjaiktól):

$\frac{2 \pi \boldsymbol{R}}{\mathbf{1 2} \boldsymbol{c} \mathbf{m}}=1,05 \approx 1 \mathrm{~km}$; ahol R (a kör sugara) a 12 generált cím kalkulált átlag távolsága adott étteremtől (depótól).

Áruterítő-rendszerben egy drón 30 perc alatt 6 megrendelést képes teljesíteni, azaz a teljes szükségletet képes kielégíteni:

$\frac{30 \text { perc }}{(1,8 \text { perc } * 2 \text { út })+(0,75 \text { perc } * 5 \text { út })+(14 \text { fel és leszállás } * 1 \text { perc })+(6 \text { kirakodás } * 1 \text { perc })+(1 \text { berakodás } * 1 \text { perc })}=1,058 ;$

ahol, a 0,75 perc az adott két megrendelő címe közti távolság átlag időszükséglete, (hármas módszer alkalmazásával számolt);

A rendszernek ez esetben 66 drónra lenne szüksége: 22 partner $* 3$ drón „ß2" terv:

Átlagtávolság a partnerek között a kiválasztott depó földrajzi helye és a partnerek közti átlagtávolság függvényében:

$\frac{2 \pi R}{22 \text { partner }}=0,29 \approx 0,3 \mathrm{~km}$; ahol R (a kör sugara) a partnerek átlag távolsága "depótól”.

Modellünkben a „depó” központi egység nézőpontjából: a partnerek és a generált címek közti átlag távolság $2,38-1,025=1,355 \approx 1,36 \mathrm{~km}$. 
Ebben az esetben viszont mind a 22 partnerhez beérkező igényt ki kell elégíteni, ezért az eddigi 30 percre eső 6 cím (12 megrendelés/óra/partner) helyett 133 címmel kalkulálunk (azaz, 267 megrendelés esti óránként összesen/2). A „ß1” tervből indulunk ki a generált címek központi egységtől való átlagtávolság azonossága miatt: $\frac{2 \pi R}{133,5 \text { cím }}=0,09 \mathrm{~km}$, ahol $\mathrm{R}$ (a kör sugara) az összes generált cím kalkulált átlag távolsága depótól. A 0,09km az e körön lévő generált címek 50\%-a (mivel 60 perc helyett, ennek felével kalkulálunk) átlagtávolsága egymástól (szomszédjaiktól). Ez a megoldás ennél jelentősebb vizsgálatot és felkészülést igényel, az adott szimuláció adatai alapján nehezen lehet következtetések levonására alkalmas eredményt alkotni, mivel csupán valószínútlenül legkedvezőbb esetben lenne elegendő a „ $\beta 1 ”$ terv, hálózat drón igénye, a fel és leszállás, valamint a be és kirakodás jelentős időszükséglete miatt.

" $\gamma$ " terv:

E rendszer drón szükséglete a „ß1” terv vizsgálatán alapul, annyi különbséggel, hogy itt a drónok két csoportjával lesz kalkulálva, egyik csoport a gyűjtő járatban résztvevő, míg másik a terítő járatban résztvevő drónok. (A szimuláció időtartama 30 perc.) Ebben az esetben a címek gyarapodása és földrajzi értelemben vett sürítése révén egy drón 30 perc alatt akár 7 megrendelést is teljesíteni tud (nevezőben 28 perc):

$\frac{30 \text { perc }}{(1,8 \text { perc } * 2 \text { út })+(0,0675 \text { perc } * 6 \text { út })+(16 \text { fel és leszállás } * 1 \text { perc })+(7 \text { kirakodás } * 1 \text { perc })+(1 \text { berakodás } * 1 \text { perc })}=1,071 ;$

Ami változik az a generált címek között (szomszédoktól) számított átlagtávolság, a kiválasztott depó földrajzi helye és a partnerek közti átlagtávolság függvényében. Számítások szerint egy drón 8 partnerhez jut el 30 perc alatt:

$(2 * 0,77$ perc $)+18$ perc +8 perc $+(7 * 0,225$ perc $)=29,115$ perc, ahol a 0,77 perc a depó és címek közti átlagtávolság időigénye (oda és visszaút), a 18 perc a 9 fel és 9 leszállás időigénye, a 8 perc a 8 rakodás időigénye (mivel ez esetben a gyűjtő járatból visszatérő drón lerakodásának idejét nem kalkuláljuk), a 0,225 perc pedig a partnerek közti (szomszédoktól való távolság) átlagtávolság megtételének időigénye a partnerek depótól való átlagtávolságának függvényében. Ezek alapján e rendszernek közel 69 drónra van szüksége a működéshez:

A gyűjtőjárathoz, mivel 1 drón 30 perc alatt legfeljebb 8 partnerhez jut el, 9 drón szükséges, kalkulálva a drónok töltésének időigényével:

$$
\frac{22 \text { partner }}{8 \text { partner }} * 1 \text { drón } * 3 \text { (töltésigény generálta váltásigény) }
$$

A terítő járathoz pedig 60 drón szükséges:

$$
\frac{133,5 \text { megrendelés }}{7 \text { teljesített }} * 1 \text { drón } * 3 \text { (töltésigény generálta váltásigény) }
$$

\section{2. Útvonaltervezés eredményei}

Az „ $\alpha ”$ terv vizsgálatának egyszerűsítése érdekében, a partnerek tetszőlegesen kiválasztott depó földrajzi helyétől számított átlagtávolságának megfelelően, kiválasztásra került egy ügyfél, amely 
depótól való távolsága megegyezik az átlaggal. A megrendeléseket (címek átlagtávolsága 2,38 km) drónunk 9,6 perc alatt teljesíti, és egy töltéssel 3,13 kalkulált átlagtávolságra található címzetthez jut el 30 perc alatt. Ez partnerenként átlagosan legalább napi 6 drón szükségességét feltételezi, kalkulálva a drónok töltésigényével (drónpárok váltásával megoldva). Az „ $\alpha$ ” terv megvalósításához legalább 132 drónra lenne szüksége a rendszernek (partnerekre való leosztásuk, azok kapacitásuk alapján valósulna meg).

A „ $\beta 1$ ” terv kiindulópontja az volt, hogy egy partner átlagos teljesítendő címe adott 30 percben 6 megrendelés. Ehhez meg kellett határozni a generált címek közti átlagtávolságot. Ennek alapján, és a korábbi számítások eredményeit felhasználva elmondható, hogy a „ß1” terv alkalmazása esetén a rendszernek csupán 66 drónra lenne szüksége.

A „ß2” terv ilyen szempontból tökéletesen nem vizsgálható, mivel előbbi esetén a kiválasztott depóból körjáratra indított drón máris hátrányban van az adott „ $\beta 1 ”$ terv drónjához képest (köszönhetően az emelkedés és leszállás, valamint a be és kirakodás jelentős mértékű időigényének).

A „ $\gamma "$ terv megvalósításához a rendszernek összesen legalább 69 drónra lenne szüksége. 9 drónra, amelyek a gyűjtőjáratban, és 60-ra, amelyek a terítőjáratban vennének részt.

A zárt rendszerű vizsgálat eredményeként elmondhatjuk, hogy esetünkben a „ $\beta 1 ”$ terv megvalósítása, azaz a terítő körjárat, vagy más megközelítés szerint az áruterítő-rendszer alkalmazása bizonyul legjobbnak a négy alternatíva közül, mely esetén a kalkulált megrendelői igények kielégítésére legkevesebb 66 drónra van szüksége e rendszernek. Ez a mennyiség kiegészül még egy tetszőleges tartalék drón-flotta számmal, az alap 66 drón valamelyikének meghibásodása esetén képes a zökkenőmentessé tenni az áruterítő-rendszert. Partnerenként tetszőleges két tartalék szállítóeszközzel számolva ez a szám eléri a 100 drónt.

\section{Következtetések}

A megvalósíthatósági tanulmányok logikai felépítését követő vizsgálatok eredményeinek bemutatása révén, több terület is körvonalazásra került. Ahogy a vizsgálataink kezdetekor is megállapítottuk, a drónos szállítási lehetőségeknél a jogi kérdések és bizonytalanságok még igen sok időt igénylő és igen jelentős befolyásoló (gátló) tényezőként maradnak meg, annak ellenére, hogy talán eddig sohasem volt égetőbb szükség egy gyors és környezetbarát szállítási módra. Mindazonáltal, jól látható, hogy az infrastruktúra adott (bár a városon belüli küldemény célba jutatása jelentős elemző-tervezői munkára szorul), a vásárlói szokások és igények kedvezőek, és a két pont közt mozgó csomagok generálta károsanyag-kibocsájtás folyamatosan nő. Azonban e kedvező feltételek ellenére alaposan át kell tekinteni az ezzel járó hatásokat, úgymint a munkahelyek megszűnése, vagy épp a lakosság és társadalom veszélyhelyzetének várható növekedése.

Az eredményeink alapján elmondható, hogy egy drónos szállításon alapuló rendszer hatékony terítőkörjáratok alkalmazásával lehet működőképes és költséghatékony. A tanulmányukban alkalmazott paraméterek szerint, a vizsgált partnereknek feladataik ellátásához legalább 66 darab drónra lenne szükség, melyek egy időben maximum 6 csomag szállítására képesek. A vizsgált készétel kiszállítási rendszer drónok általi automatizálása a vizsgálatok alapján megvalósítható, melynek révén egy időben 
a rendszer 22 drónt indíthat körjáratra. Azonban ilyen feltételek mellett viszonylag magasnak nevezhető a csomagszállítási céllal adott város légterében működő drónok száma, melynek menedzselése nagy feladatot igényelne. Ebben az esetben újabb kérdések merülnek fel, mint a biztonságos üzemeltethetőség és a zajszennyezés. Jelentős figyelmet kell fordítani a kapcsolatépítésre és a műszaki folyamatok ütemezésére, és annak minőségi tényezőire, amely jelentősen meghatározhatja a projekt eredményeit (kiváltképp megoldásra szorul az időjárási viszonyok okozta kockázati tényező). Az előzetes helyzetfelmérés szakaszában különösképp figyelni kell a piaci visszajelzésekre, melyeket a drón általi szállítás újdonságtartalma jelentősen torzíthat. Bár az új szállítási mód egyik előnye a gazdaságos és környezetbarát energiafelhasználásban rejlik, mégis jelentős figyelmet kell fordítani az útvonaltervezésre, valamint a költséghatékony műszaki fejlesztésekre, illetve a nyomon követhetőségre. A drónok szállításban való alkalmazásának lehetőségeit a drón technológia adottságai (mekkora a drón teherbírása, mekkora utat képes megtenni, milyen sebességgel képes közlekedni, mindezt milyen időjárási körülmények közt, stb.), a jogszabályok, a különböző érdekképviseletek és szakszervezetek, valamint az általános elfogadottság fogja meghatározni. A téma szerteágazósága miatt a közeljövő feladata annak további elemzése, fókuszálva a kapcsolódó jogi, illetve alkalmazási területre vonatkozó kérdésekre.

\section{Hivatkozások}

[1] J. Oláh - Gy. Karmazin - K. Pető - J. Popp (2017) Information technology developments of logistics service providers in Hungary. International Journal of Logistics Research And Applications, 21 (3) pp. 332-344..

[2] J. Pucsek J. (2011) Az elosztási-, áruszállítási folyamatok logisztikája. In: H. O. Berkesné [et al.] (szerk.): Logisztikai rendszerek és elméletek. Universitas-Győr Nonprofit Kft., Győr. pp. 99-133. ISBN: 978-963-9819-67-2

[3] V. L. Pusztai (2015) Kereskedelmi drón használat logisztikai feladatokra. Logisztikai híradó, 25 (6) pp. 26-28.

[4] M. Arjomandi (2016) Classification of Unmanned Vehicles. The University of Adelaide, Australia. $48 \mathrm{p}$.

[5] R. Juhász (2015) Lézerszkennerrel, pilóta nélkül: Drónok és épületek. Élet és Tudomány, 70 (36) pp. 1126-1127.

[6] M. Heutger (2014) Unmanned Aerial Vehicles In Logistics. DHL Trend Research. Troisdorf, Germany, p. 20.

[7] K. Kakaes (2015) Drone regulation-privacy and property rights. In: K. Kakaes - F. Greenwood - M. Lippincott - S. Dosemagen - P. Meier - S. Wich (2015) Drones and Aerial Observation: New Technologies for Property Rights, Human Rights, and Global Development: A Primer. New America. pp. 29-34. 
[8] G. Williams (2015) What You Should Know About Using Drones for Your Business. https://www.americanexpress.com/us/small-business/openforum/articles/needknow-want-drone-business/

[9] M. Lewontin (2015) Why Walmart is investing in flying delivery drones. http://www.csmonitor.com/Technology/2015/1027/Why-Walmart-is-investing-inflying-delivery-drones

[10] T. Csapóné Riskó - Á. Péntek (2014) A tudatos fogyasztás megjelenési formái. Táplálkozásmarketing, 1 (1-2) pp. 73-80. 